\title{
SISTEM PENGAWASAN DAN PERINGATAN DINI KEBENCANAAN PADA GOA TERINTEGRASI MENGGUNAKAN IOT
}

\author{
Danang Arif Rahmanda(1), Awang Hendrianto Pratomo (2), Oliver Samuel Simanjuntak ${ }^{(3)}$ \\ Jurusan Teknik Informatika Fakultas Teknik Industri UPN "Veteran" Yogyakarta \\ Jl. Babarsari 2 Tambakbayan Yogyakarta \\ email: darifrahmanda@gmail.com ${ }^{(1)}$, awang@upnyk.ac.id(2), oliver.simanjuntak@upnyk.ac.id(3)
}

\begin{abstract}
Smart city is a system that provides development in the city that is used with the aim to be better and provide services to the community to fulfill a decent life. Early Warning System (EWS) in the environmental field is part of an intelligent environment to provide an early warning of an event such as a disaster that is notified to the public. The application of the early warning system is applied to the environment which includes natural tourism areas, one of which is a cave. The environment in the form of formation due to natural processes that pierce rocks. With the existence of a monitoring and early warning system at this time which is a system that is very needed, remembering disasters that often occur in realtime and sometimes unpredictable. From the old way of observing and notifying information about the conditions inside the cave, it can be done quickly with continuously updated data. The system is designed using a DHT11 sensor as an air humidity sensor, DS18 as an outer space sensor, BMP180 as a sensor for indoor room temperature and air pressure, FC28 as a soil moisture sensor, rain sensor as a rainfall sensor. Data obtained from each sensor will be sent to a database that is in the cloud server, so the data will continue to be updated. The results of sensor testing obtained have a difference that is not far from the real value tested by another measuring device when the power or voltage given to the sensor is higher. At a voltage of 1 ampere for the temperature sensor gives a value of 30 degrees Celsius while with a thermometer is 32 degrees Celsius, and at a voltage of 5 amperes the temperature sensor and thermometer are worth 29 degrees Celsius at the same time. In the air humidity sensor, with a voltage of 1 ampere gets $63 \%$ while in fact the value is $65 \%$, and with a voltage of 5 amperes, in real humidity and using sensors valued at $77 \%$ at the same time.
\end{abstract}

Keywords : Smart City, Internet of Things, surveillance, early warning, cave

\begin{tabular}{l} 
Abstrak \\
Smart city merupakan sistem yang memberikan perkembangan pada kota yang digunakan \\
dengan tujuan untuk lebih baik serta memberikan pelayanan terhadap masyarakat untuk \\
memenuhi kehidupan yang layak. Peringatan dini atau Early Warning System (EWS) pada \\
bidang lingkungan merupakan bagian dari lingkungan cerdas untuk memberikan sebuah \\
peringatan dini suatu kejadian seperti kebencanaan yang diberitahukan kepada masyarakat. \\
Penerapan sistem peringatan dini tersebut di terapkan pada lingkungan yang meliputi daerah \\
wisata alam, salah satunya gua. Gua merupakan suatu lingkungan berupa bentukan akibat \\
proses alam yang melubangi batuan. Dengan adanya sistem pengawasan dan peringatan dini \\
saat ini yang merupakan sistem yang sangat dibutuhkan, mengingat bencana yang sering \\
realtime terjadi dan terkadang yang tidak dapat diduga. Dari cara pengamatan dan \\
pemberitahuan informasi yang lama mengenai keadaan didalam gua ini dapat dilakukan \\
dengan cepat dengan data yang diperbaharui secara secara terus menerus. Sistem \\
pengawasan yang dirancang dengan menggunakan sensor DHT11 Sebagai Sensor \\
Kelembaban Udara, DS18 Sebagai Sensor Ruang Luar,BMP180 Sebagai Sensor Suhu Ruang \\
Dalam dan Tekanan Udara, FC28 Sebagai Sensor Kelembaban Tanah, Rain Gaug Sebagai \\
Sensor Curah Hujan. Data yang didapatkan dari masing-masing sensor akan dikirimkan \\
kedalam database yang berada dalam cloud server, sehingga data akan terus diperbaharui. \\
Hasil dari pengujian sensor didapatkan memiliki selisih yang tidak jauh dengan nilai nyata yang \\
diuji dengan alat pengukur lain ketika daya atau tegangan yang diberikan pada sensor lebih \\
tinggi. Pada tegangan 1 ampere untuk sensor suhu memberikan nilai 30 derajat selsius \\
\hline
\end{tabular}


sedangkan dengan termometer adalah 32 derajat selsius, dan pada tegangan 5 ampere sensor suhu dan thermometer bernilai 29 derajat selsius diwaktu yang sama. Pada sensor kelembaban udara, dengan tegangan 1 ampere mendapatkan $63 \%$ sedangkan pada nilai nyatanya $65 \%$, dan dengan tegangan 5 ampere, pada kelembaban nyata dan menggunakan sensor bernilai $77 \%$ diwaktu yang sama.

Kata kunci: Smart City, Internet of Things, Pengawasan, Peringatan Dini, Gua

\section{PENDAHULUAN}

Smart city atau yang sering disebut dengan kota cerdas merupakan sistem yang memberikan perkembangan pada kota agar lebih baik serta memberikan pelayanan terhadap masyarakat untuk memenuhi kehidupan yang layak. Smart city merupakan sistem kota yang untuk membangun hubungan antar tantangan kota yang teridentifikasi dan proyek cerdas yang dirancang untuk menyelesaikan tantangan kota dengan baik (Monzon, 2015). Konsep dari smart city sendiri sudah berevolusi dari pelaksanaan proyek spesifik hingga penerapan strategi global untuk mengatasi tantangan kota yang lebih luas dan memberikan kehidupan yang layak bagi manusia dan sekitarnya tanpa merusak lingkungan. Smart city dikembangkan dalam berbagai bidang atau dimensi dalam kehidupan masyarakat diantaranya lingkungan, ekonomi, mobilitas, pemerintahan, gaya hidup, dan masyarakat itu sendiri.

Smart Environment atau lingkungan cerdas merupakan pengembangan smart city yang dikembangkan untuk meningkatkan kemudahan dalam kehidupan masyarakat baik secara langsung ataupun dengan memberikan informasi sebagai peringatan atau pencegahan. Peringatan dini atau Early Warning System (EWS) pada bidang lingkungan merupakan bagian dari lingkungan cerdas untuk memberikan sebuah peringatan dini suatu kejadian seperti kebencanaan yang diberitahukan kepada masyarakat agar masyakarat mengetahui apa yang sedang terjadi di lingkungannya saat itu (Kussul, Skakun, Shelestov, Kussul, \& Yailymov, 2014). Pada penerapan sistem peringatan dini tersebut di terapkan pada lingkungan yang meliputi daerah wisata alam, daerah yang rawan bencana dan dilindungi, ataupun daerah lingkungan sekitar masyarakat. Daerah yang menjadi obyek wisata adalah tempat atau keadaan alam yang memiliki sumber daya wisata yang dibangun dan dikembangkan sehingga mempunyai daya tarik dan diusahakan sebagai tempat yang dikunjungi wisatawan, adapun beberapa contoh daerah wisata alam seperti pantai, gunung, hutan, danau, kawah, air terjun, gua dan lain sebagainya.

Gua merupakan suatu lingkungan berupa bentukan akibat proses alam yang melubangi batuan, dan lubang tersebut dapat berbentuk lorong yang panjang, atau dapat pula sebagai ceruk yang dalam (Harmony \& Agus Joko Pitoyo, 2012). Berdasarkan pembentukannya, gua dibagi menjadi dua jenis, yaitu gua alami dan gua buatan. Gua alami terbentuk dari proses seperti proses vulkanik, ataupun proses pelapukan batuan, pembentukan yang terjadi selama ratusan hingga ribuan tahun hingga membentuk pola tertentu. Faktor pembentuk pada gua alami adalah aliran air $(\mathrm{H} 2 \mathrm{O})$ yang melewati celah dan lapisan batuan, temperatur suhu, kelembaban udara. Aliran yang terus menerus inilah yang melarutkan batu gamping menjadi partikel yang terus dan tumbuh menjadi stalaktit dan stalakmit (Pangkep, 2008). Sedangkan, gua buatan merupakan lorong yang sengaja di bentuk oleh manusia, dan lebih dikenal sebagai terowongan.

Gua dimasa lampau digunakan sebagai tempat tinggal, kini digunakan sebagai tempat wisata dan aktivitas olahraga ekstrem. Menurut beberapa aktivis penjelajah gua, kegiatan penelusuran didalam gua tidak dapat dilakukan jika kondisi didalam gua mengalami fluktuasi atau perubahan yang cukup ekstrem, salah satunya seperti kekurangan oksigen dan dapat mengakibatkan hiperventilasi saat keadaan tekanan konsentrasi udara $\mathrm{CO} 2$ (Karbon dioksida) lebih besar daripada tekanan normal yang berkisar $0.03 \%$, atau konsentrasi karbon dioksida yang lebih dari $10 \%$ dapat mengakibatkan gangguan sistem pernafasan pada tubuh dan mengakibatkan kematian dalam beberapa menit saja (Smith, \& Kermani, 1997). Sementara faktor-faktor lain didalam gua yang mengakibatkan tinggi rendahnya kelembaban udara adalah suhu, tekanan udara, pergerakan angin, kuantitas dan kualitas penyinaran, serta adanya vegetasi. Tingkat kelembaban udara juga dapat mempengaruhi kesehatan tekanan darah pada manusia, jika berada di bawah normal akan mengakibatkan pengerutan saluran darah. Dari faktor-faktor yang 
terjadi didalam gua ini, mengakibatkan mampu atau tidaknya dilakukan aktivitas didalam gua dan memerlukan pengawasan. Dari faktor-faktor keadaan alam yang terjadi didalam gua memerlukan pengawasan yang dapat menginformasikan kepada masyarakat yang akan melakukan aktivitas didalam gua.

Sistem pengawasan dan peringatan dini saat ini merupakan sistem yang sangat dibutuhkan dari sebuah perkembangan teknologi yang semakin maju untuk melakukan pengawasan. Mengingat bencana yang sering terjadi dan terkadang tidak dapat diduga, disaster management atau managemen kebencanaan merupakan serangkaian aktivitas dan upaya untuk menanggulangi ataupun mengurangi resiko dan dampak dari bencana alam yang terjadi untuk tetap menjaga lingkungan alam yang di huni manusia (Singh, 2016). Manajemen kebencanaan juga merupakan salah satu bagian dari early warning system yang saat ini sangatlah dibutuhkan sebagai suatu sistem yang memberikan pelayanan dan informasi yang disampaikan kepada masyarakat. Cara yang ada saat ini dalam mengamati keadaan yang ada pada gua, dapat memakan waktu untuk memastikan aman atau tidaknya keadaan didalam gua tersebut dan penyampaian informasi kepada masyarakat yang akan melakukan aktivitas hanya dapat disampaikan ketika masyarakat sudah berada lokasi, ataupun pihak pengelola menginformasikan melalui media sosial.

Permasalahan dari cara pengamatan dan pemberitahuan informasi yang lama mengenai keadaan aktivitas alam didalam gua ini, pengamatan dapat dilakukan dengan cepat dengan data yang diperbaharui secara realtime secara terus menerus dengan teknologi Internet of Thing (IOT) yang memanfaatkan alat berupa sensor-sensor seperti sensor curah hujan, sensor suhu, sensor tekanan udara, sensor kelembaban tanah dan sensor kelembaban udara yang diletakkan didalam gua. Data yang didapatkan dari sensor-sensor tersebut akan dimasukkan kedalam database yang diletakkan kedalam cloud server, sehingga dari data yang didapat akan diolah menjadi informasi yang dapat diakses oleh masyarakat yang akan mengunjungi wisata gua, yang akhirnya masyarakat dapat mengetahui status dan kondisi gua memungkinkan untuk dikunjungi.

\section{TINJAUAN PUSTAKA}

\subsection{Pengamanan Gua}

Gua adalah sebuah lubang alami yang terbentuk pada tanah atau batu dengan proses pelapukan batuan dan seringkali meluas jauh dibawah tanah (Harmony \& Agus Joko Pitoyo, 2012). Proses pembentukan gua alami merupakan hasil pelapukan batuan, diantaranya adalah batuan gamping, pada batuan lava basalt, dan beberapa jenis batuan lain yang mengalami abrasi ataupun erosi sehingga menjadi sebuah struktur tertentu. Dari jenis pembentukannya, gua yang terbentuk pada batuan gamping adalah yang paling banyak dan berkembang menjadi bentang alam karst. Karst adalah istilah yang digunakan untuk menggambarkan gaya lanskap khusus atau bentang alam yang berisi gua dan sistem air bawah tanah yang luas yang dikembangkan di batuan yang sangat mudah larut seperti batu kapur, marmer, dan gipsum. Daerah yang luas dari wilayah kontinental bebas es di Bumi diliputi oleh karst yang dikembangkan di batuan karbonat, dan sekitar $20-25 \%$ populasi global sangat bergantung atau sepenuhnya bergantung pada air tanah yang diperoleh darinya. Sumber daya ini mendapat tekanan yang meningkat dan membutuhkan pengelolaan rehabilitasi dan kelestarian yang besar.

Kegiatan penelusuran gua adalah aktifitas yang mengandung resiko tinggi (high risk activity). Hal itu disebabkan karena gua mempunyai medan yang berbeda dengan yang kita hadapi seharihari. Bahaya penelusuran gua dapat dibagi menjadi:

\section{Antroposentrisme}

Antroposentrisme yaitu bahaya terhadap manusia (penelusur gua). Dapat disebabkan oleh faktor manusia, bahaya ini dapat berupa tergelincir, terjatuh, terantuk, kejatuhan, tersesat, tenggelam, kedinginan, dehidrasi, gigitan binatang berbisa, dan lain-lain. Perlatan yang digunakan, setiap penelusur gua harus terampil dalam penguasaan dan penggunaan alat. Pemakaian peralatan merupakan salah satu hal yang perlu diperhatikan setiap penelusur gua. Karena pemakaian peralatan dengan cara yang salah selain merusak alat tersebut, juga bisa berakibat fatal. Ini sangat berbahaya mengingat penelusur gua sangat tergantung pada alat. Pemasangan pengamanan atau beban yang berlebihan juga harus diperhatikan oleh penelusur gua. Faktor 
gua, dapat menimbulkan bahaya karena kemungkinan yang tak terduga seperti runtuhan atap/dinding karena gempa, juga karena adanya gas beracun dalam gua tersebut.

\section{Speleosentrisme}

Speleosentrisme yaitu bahaya terhadap gua yang disebabkan oleh manusia (penelusur gua). Diakui atau tidak, kegiatan penelusuran gua bagaimana pun juga akan memberikan kerusakan terhadap gua itu sendiri, kerusakannya dapat berupa rusaknya ornamen-ornamen yang ada dalam gua, terganggunya biota dalam gua dan lain sebagainya. Tinggal bagaimana komitmen dari para penelusur gua untuk dapat meminimal terjadi kerusakannya tersebut.

Kecelakaan lain yang sering terjadi adalah keracunan atau kekurangan oksigen (hipoksia). Adapun kadar toleransi oksigen akan terbagi seperti berikut:

Tabel 1. Kadar Sisa Oksigen

\begin{tabular}{|l|l|l|}
\hline No & Kadar Sisa Oksigen & Kondisi \\
\hline 1 & $20 \%$ & Udara normal \\
\hline 2 & $16 \%$ & Lilin tidak menyala \\
\hline 3 & $15 \%$ & $\begin{array}{l}\text { Pada raut muka terdapat gejala } \\
\text { hipoksia }\end{array}$ \\
\hline 4 & $12 \%$ & Hipoksia serius \\
\hline 5 & $8-10 \%$ & Lampu karbit tidak menyala \\
\hline
\end{tabular}

Kekurangan oksigen biasanya terjadi dilorong-lorong sempit, ducking, dan juga sump. Pemakaian obor dan lampu petromak tidak dianjurkan karena akan menambah kadar karbondioksida $\left(\mathrm{CO}_{2}\right)$. Gas $\mathrm{CO}$ sangat ditakuti oleh orang-orang yang melakukan aktivitas olahraga ekstrem dalam gua, hal ini dikarenakan gas CO dapat mengakibatkan kematian, disamping itu tidak berbau dan tidak berwarna. Gas $\mathrm{CO}$ dapat timbul akibat peledakan dinamit dan penyalaan api unggun pada gua, ketika bernafas dapat menghisap asap diluar gua. Beberapa macam gas didalam gua, diantaranya :

a) Gas Nitro, menyebabkan bibir dan kulit kebiruan, nyeri pada kepala dan tekanan darah menurun drastis. Gas ini tidak berwarna hitam dan tidak berbau.

b) Gas Sulfur, terdapat pada daerah gunung berapi (gua lava), berbau seperti telur busuk dan tidak berwarna. Dapat diatasi dengan masker industri atau bauan kopi.

c) Udara gua yang penuh debu, membuat sesak nafas, sakit saat bernafas dan batuk kering. Dapat diatasi dengan masker, biasanya terdapat pada gua-gua yang kering atau gua-gua yang tidak aktif lagi pembentukkannya.

d) Udara gua yang mudak meledak atau terbakar, gas metan, gua ini sangat berbahaya jika menggunakan lampu karbit atau korek api.

Adapun indikator lain yang berpengaruh pada aktivitas didalam gua adalah tinggi rendahnya kelembaban udara yang juga dipengaruhi oleh suhu pada lingkungan gua. angka relative yang didapatkan dari perbandingan kelembaban dan suhu dapat dilihat pada gambar 2.1 berikut. Pada gambar tersebut, angka relatif terbagi menjadi 5 kategori, yaitu kering, baik, cukup baik, kurang baik, dan sangat kurang baik. (Hayati, dkk, 2013) 


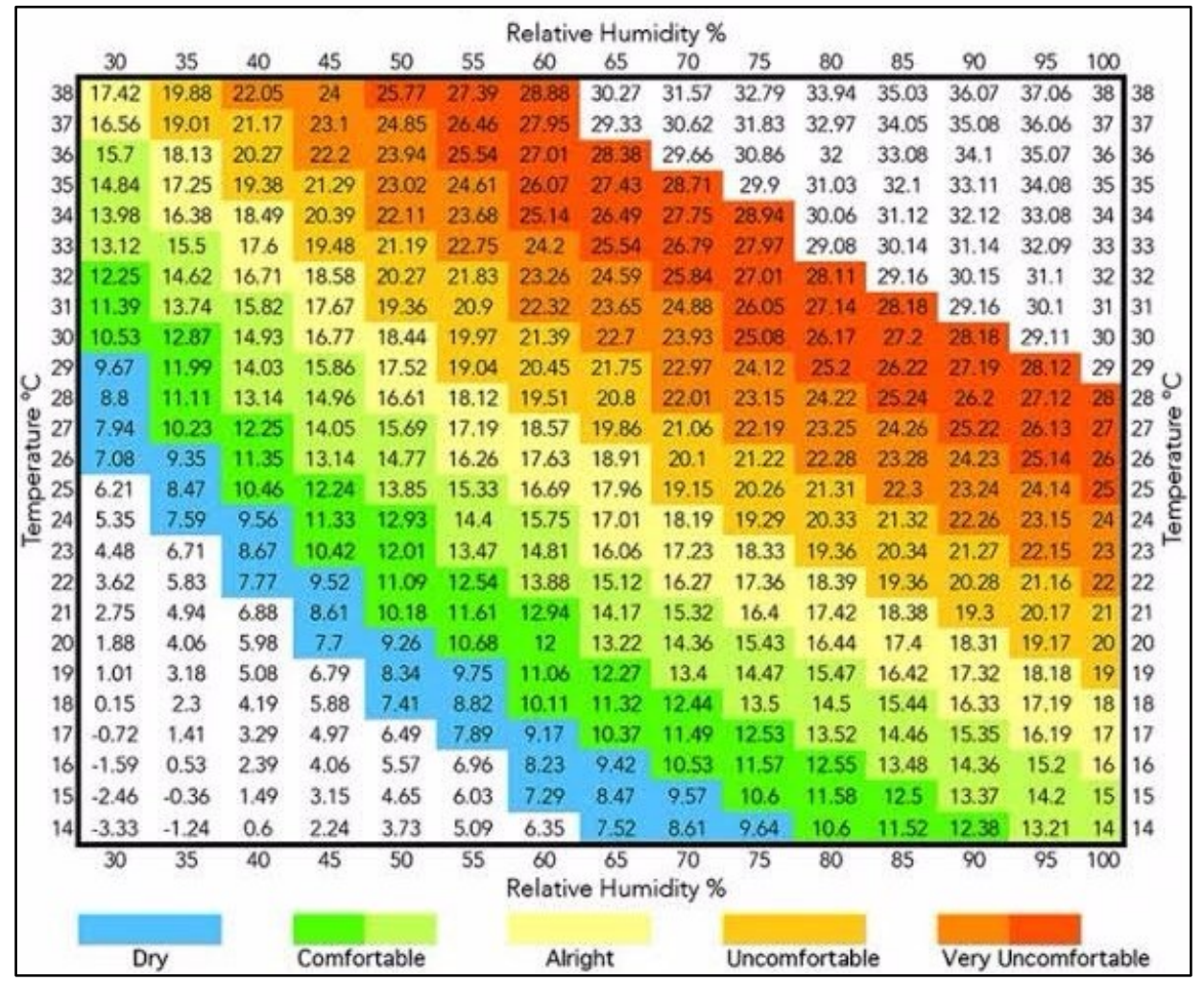

Gambar 1. Relativitas Kelembaban dan Suhu

Selain suhu dan kelembaban, faktor lain pada yang mempengaruhi aktivitas gua adalah curah hujan, dikutip dari laman resmi BMKG, dengan tingkatan 4 kategori curah hujan seperti pada Gambar 2 berikut. (BMKG, 2018)

\begin{tabular}{|c|c|}
\hline \multicolumn{2}{|c|}{ CURAH HUJAN $(\mathrm{mm})$ : } \\
\hline $0-20$ & \\
\hline $20-50$ & RENDAH \\
\hline $50-100$ & \\
\hline $100-150$ & \\
\hline $150-200$ & MENENGAH \\
\hline $200-300$ & \\
\hline $300-400$ & TINGGI \\
\hline $400-500$ & \\
\hline$>500$ & SANGAT TINGGI \\
\hline
\end{tabular}

Gambar 2. Tingkat curah hujan

\subsection{Zona Lingkungan Gua}

Menurut Moore dan Sullivan, 1978 membagi lingkungan gua menjadi 3 bagian, yaitu:

a) Zona terang (Twilight Zone)

Merupakan daerah yang dekat dengan mulut gua yang memungkinkan mendapat sinar matahari secara langsung. Zona ini memiliki densitas organisme yang tinggi.

b) Zona peralihan (Middle Zone)

Zona ini dicirikan dengan adanya daerah gelap total, tetapi memiliki kelembaban dan temperature yang berfluktuasi pada siang dan malam hari. Zona ini masih bisa mendapatkan cahaya matahari walaupun tidak secara langsung, yaitu melalui pantulan. 
c) Zona gelap (Totally Dark Zone)

Merupakan ciri gua yang memiliki kegelapan abadi, dimana secara alami tidak ada cahaya matahari yang bisa masuk. Temperaturan dan kelembaban relative konstan sepanjang tahun, kalaupun ada variasi mempunyai fluktuasi kecil.

Sejalan dengan perubahan zonasi diatas, tekanan atmosfer dan suhu dalam gua akan semakin menurun. Adanya penurunan tersebut mengakibatkan aliran udara didalam gua sangat kecil.

\subsection{Early Warning System}

Sistem Peringatan Dini (Early Warning System) merupakan serangkaian sistem untuk memberitahukan akan timbulnya kejadian alam, dapat berupa bencana maupun tanda-tanda alam lainnya. Peringatan dini pada masyarakat atas bencana merupakan tindakan memberikan informasi dengan bahasa yang mudah dicerna oleh masyarakat (Alphonsa A and Ravi G 2016). Namun demikian menyalakan sirine hanyalah bagian dari bentuk penyampaian informasi yang perlu dilakukan karena tidak ada cara lain yang lebih cepat untuk mengantarkan informasi ke masyarakat. Harapannya adalah agar masyarakat dapat merespon informasi tersebut dengan cepat dan tepat. Kesigapan dan kecepatan reaksi masyarakat diperlukan karena waktu yang sempit dari saat dikeluarkannya informasi dengan saat (dugaan) datangnya bencana (Patkcornell 1986). Kondisi kritis, waktu sempit, bencana besar dan penyelamatan penduduk merupakan faktor-faktor yang membutuhkan peringatan dini. Semakin dini informasi yang disampaikan, semakin longgar waktu bagi penduduk untuk meresponnya.

Keluarnya informasi tentang kondisi bahaya merupakan muara dari suatu alur proses analisis data-data mentah tentang sumber bencana dan sintesis dari berbagai pertimbangan. Ketepatan informasi hanya dapat dicapai apabila kualitas analisis dan sintesis yang menuju pada keluarnya informasi mempunyai ketepatan yang tinggi. Dengan demikian dalam hal ini terdapat dua bagian utama dalam peringatan dini yaitu bagian hulu yang berupa usaha-usaha untuk mengemas datadata menjadi informasi yang tepat dan menjadi hilir yang berupa usaha agar infomasi cepat sampai di masyarakat.

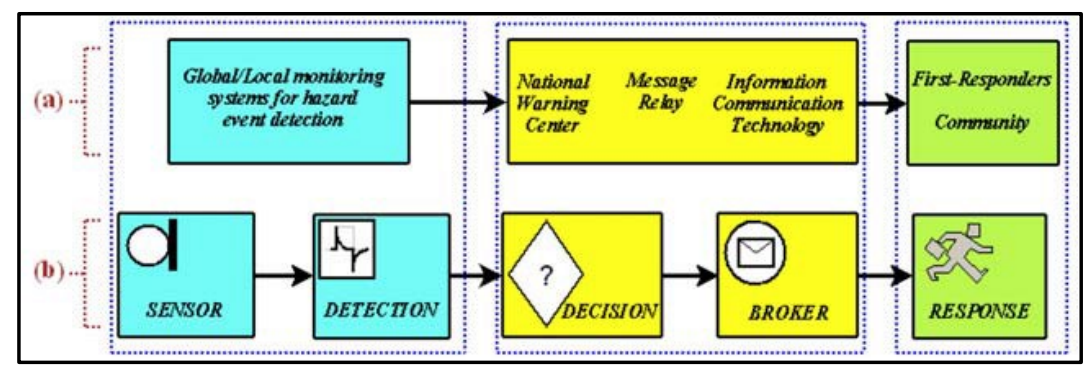

Gambar 3. Arsitektur early warning sistem

Arsitektur sistem peringatan dini berawal pada EWS Client yang mana sistem tersebut memberikan data deteksi dari alat lalu menjadi layanan peringatan yang di kembalikan pada sistem EWS client. Setelah mendapatkan layanan, sistem EWS client melakukan penilaian layanan pada database dan melakukan aksi eksekusi penilaian layanan seperti hasil lingkungan gua setelah itu sistem melakukan analisa dan visualisasi melalui peta layanan yang tersedia dengan memberikan titik-titik visualisasi peringatan hasil penilaian dan penentuan dari data alat deteksi tersebut.

\subsection{Disaster Management}

Disaster Management adalah suatu proses atau strategi yang diterapkan sebelum, selama atau setelah jenis peristiwa bencana terjadi. Proses ini dapat dimulai setiap kali sesuatu hal mengancam untuk mengganggu operasi normal atau menempatkan kehidupan masyarakat beresiko (Wladdimiro et al., n.d.). Pemerintah di semua tingkatan serta banyak perusahaan membuat rencana bencana mereka sendiri yang memungkinkan untuk mengatasi berbagai bencana dan kembali berfungsi normal secepat mungkin. 


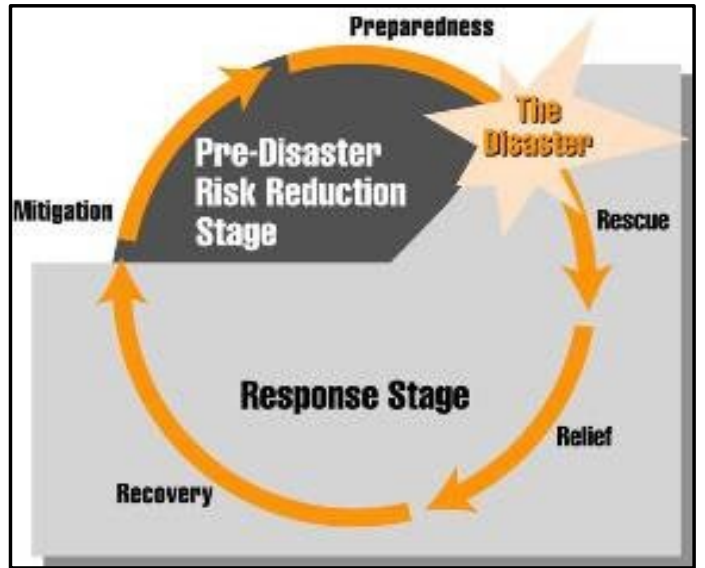

Gambar 4. Arsitektur disaster management

\subsection{Internet of Things}

Internet of Things sebagai sebuah sistem dimana benda-benda di dunia fisik dan sensor yang disisipkan ke dalam benda tersebut terhubung ke internet melalui koneksi internet kabel maupun nirkabel (Lopez Research 2013). Setiap benda yang menggunakan loT akan memiliki banyak sesnsor di dalamnya yang digunakan untuk mengambil data kondisi seperti lokasi, gerakan, getaran, dan temperatur. Sensor tersebut akan menyediakan informasi yang dibutuhkan oleh perusahaan maupun perorangan. Data dalam loT berbeda dengan komputasi tradisional pada umumnya. Data loT dapat berukuran sangat kecil dan sering ditransmisikan. Jumlah perangkat yang terhubung di dalam loT jauh lebih banyak daripada komputasi tradisional.

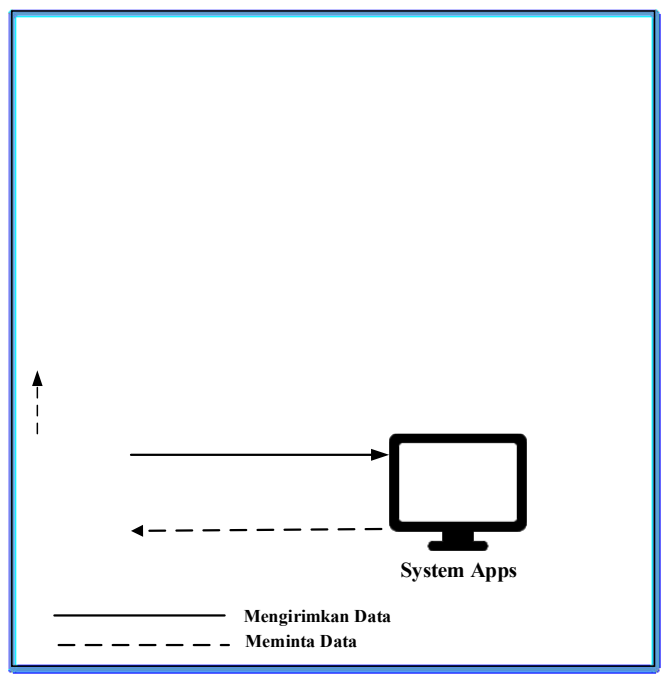

Gambar 5. internet of things pada lingkungan.

Pada arsitektur tersebut, penggunaan alat digunakan untuk upload dan download data pada database cloud dimana database tersebut juga membagikan data nya ke web / mobile app.

\section{METODOLOGI PENELITIAN}

Metodologi penelitian yang digunakan dalam pembangunan sistem dan analisis kebutuhan sistem. Adapun tahapan penelitian dengan metodologi pengembangan sistem waterfall yang dilakukan pada penelitian ini adalah pengumpulan data, perancangan sistem, dan pengujian 
sistem.

\subsection{Perancangan Arsitektur Sistem}

Perancangan arsitektur sistem yang dibangun terdiri dari beberapa entitas yaitu pengguna yang dapat mengakses sistem untuk mengakses informasi lokasi yang berisi data iklim berupa chart dan data detail dapat dicetak oleh pengguna. Sistem pengawasan dan peringatan dini banjir pada gua ini akan memberikan informasi secara akurat kepada pennguna mengenai keadaan curah hujan dan iklim pada suatu lokasi. Data yang didapatkan dari alat akan dikirimkan melalui cloud, alat sebelumnya akan didaftarkan oleh admin, satu alat berada pada satu lokasi untuk memberikan informasi mengenai curah hujan, suhu, dan kelembaban dalam gua sebagai acuan dalam penentuan kondisi didalam gua, adapun perancangan sistem yang akan dibangun tampak seperti pada Gambar 6 berikut.

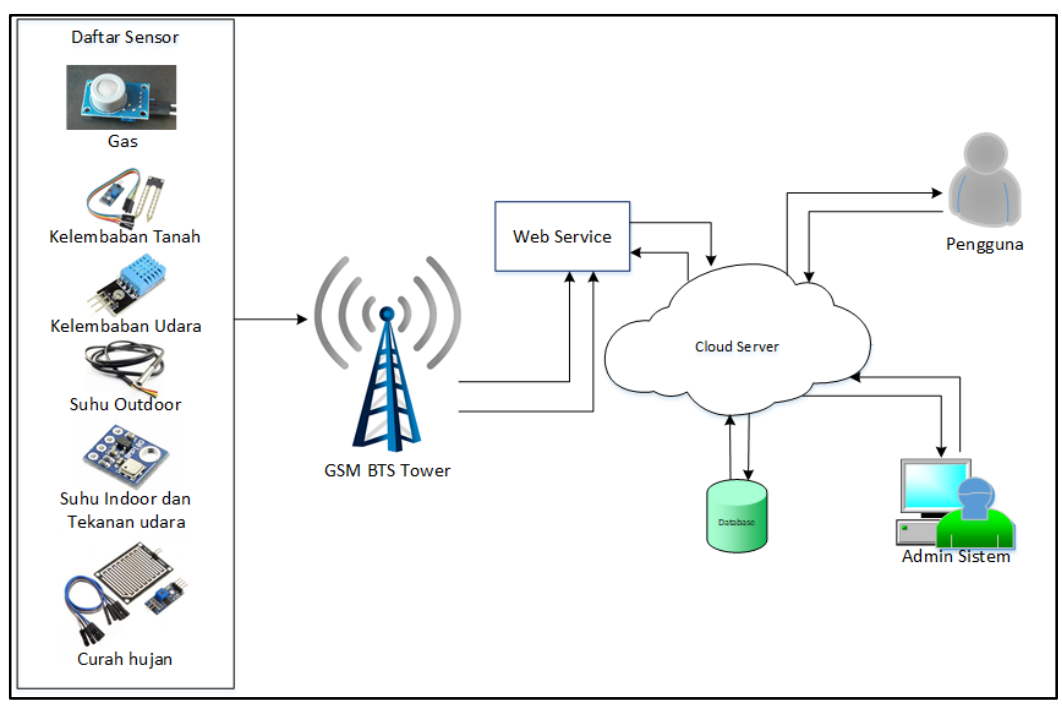

Gambar 6. Arsitektur Sistem (IAAS, PAAS, SAAS Cloud)

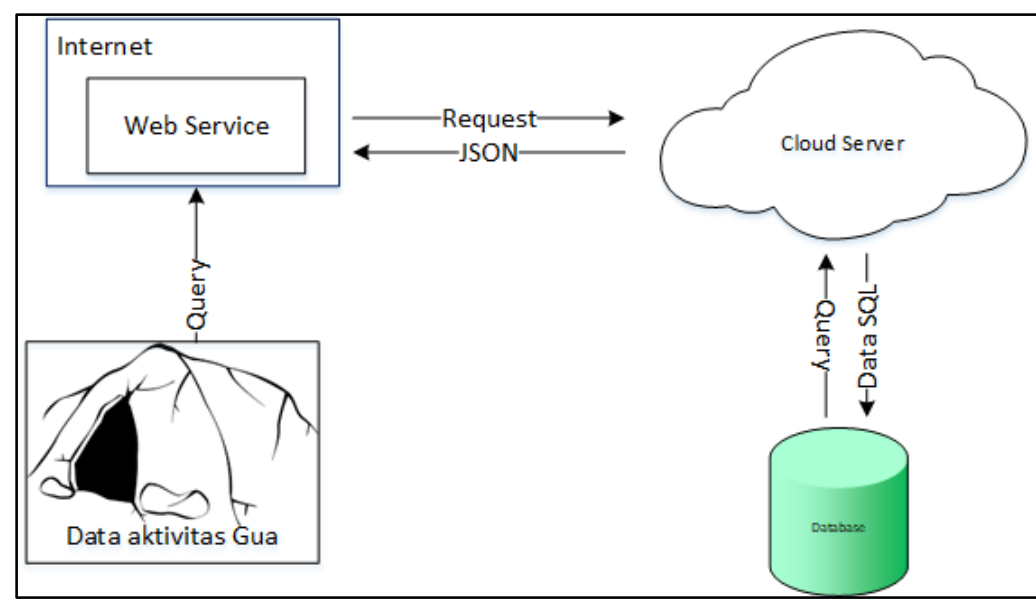

Gambar 7. Arsitektur Cloud Service 


\subsection{Perancangan Hardware}

Pada penelitian ini, perancangan hardware yang berupa sensor-sensor antara lain DHT11, BMP180, DS18, FC28 dirancang seperti pada gambar 3.3, power supply menggunakan jack dc pada board arduino sebagai daya untuk menyalakan sensor, kelembaban udara dan suhu ruang akan akan mengambil data kelembaban udara, tekanan udara dan suhu ruang dalam, suhu ruang luar, gas karbon, kelembaban tanah, kelembaban ruang dari dalam gua yang akan dikirimkan ke database cloud dari jaringan operator yang digunakan pada SIM GSM/GPRS begitu seterusnya.

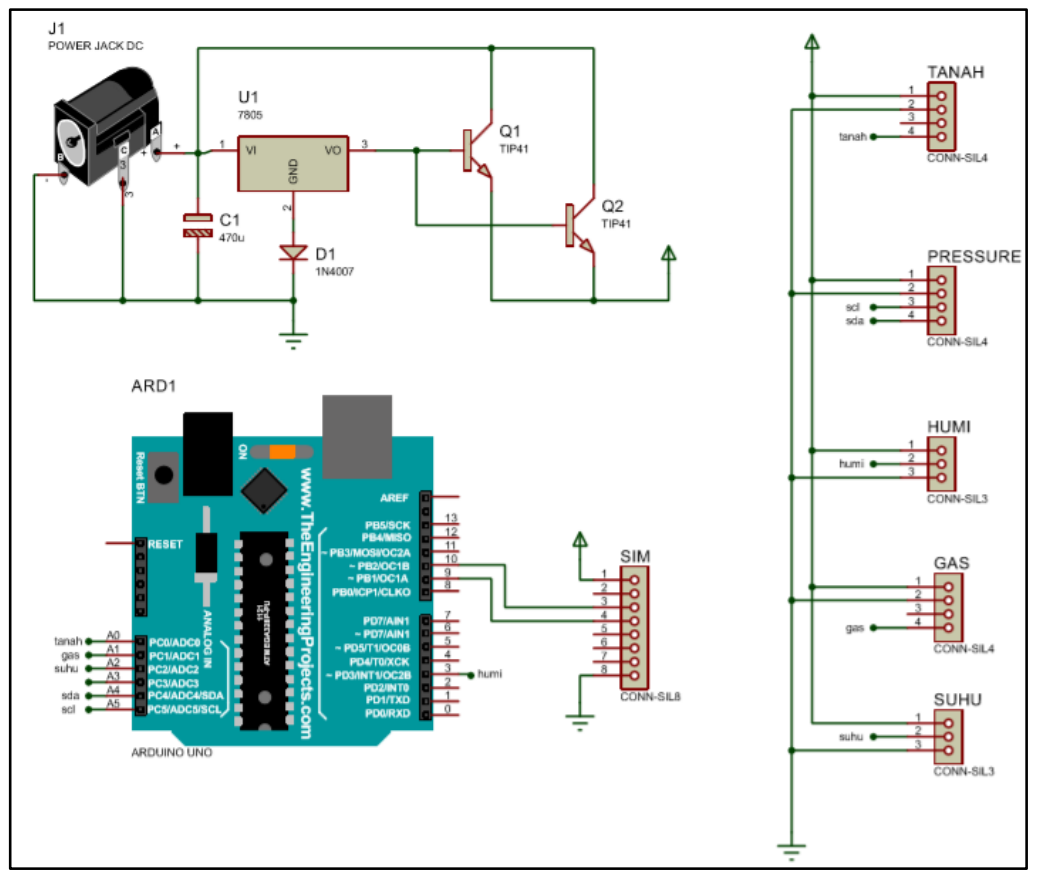

Gambar 8. Perancangan hardware

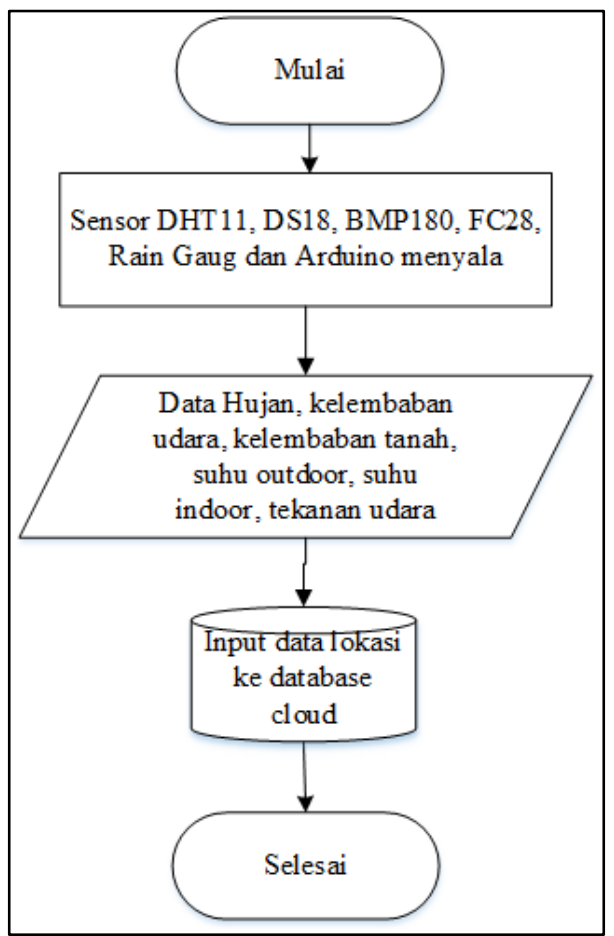

Gambar 9. flowchart monitoring 


\subsection{Perancangan Proses}

Tahap perancangan proses software sangat diperlukan dalam pembangunan sistem pengawasan dan peringatan dini banjir pada gua, perancangan ini digambarkan dengan data flow diagram sebagai aliran data pada suatu proses dan terpecah menjadi level 0 , level 1 dan level 2 sebagai berikut.

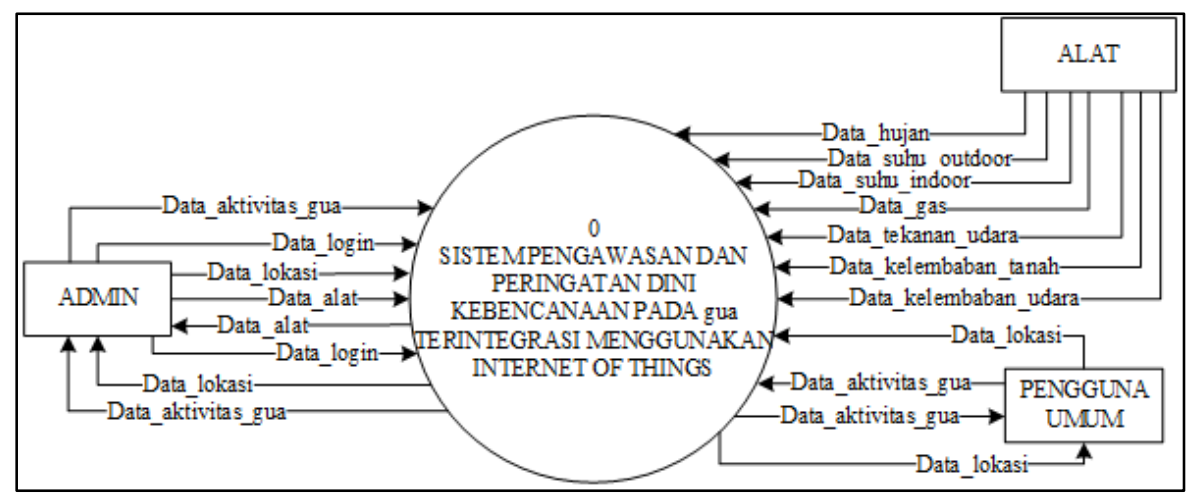

Gambar 10. DFD Level 0

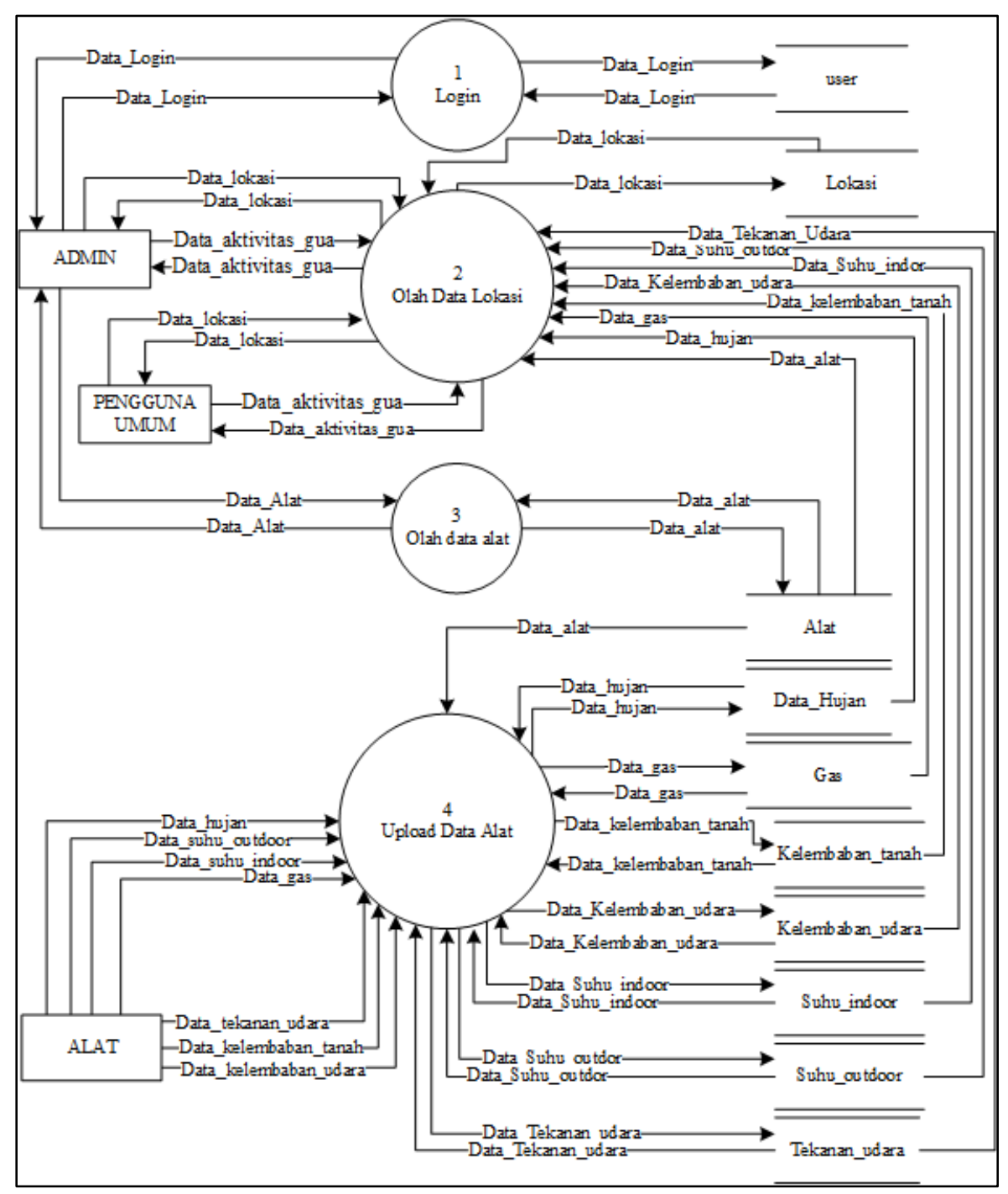

Gambar 11. DFD Level 1 


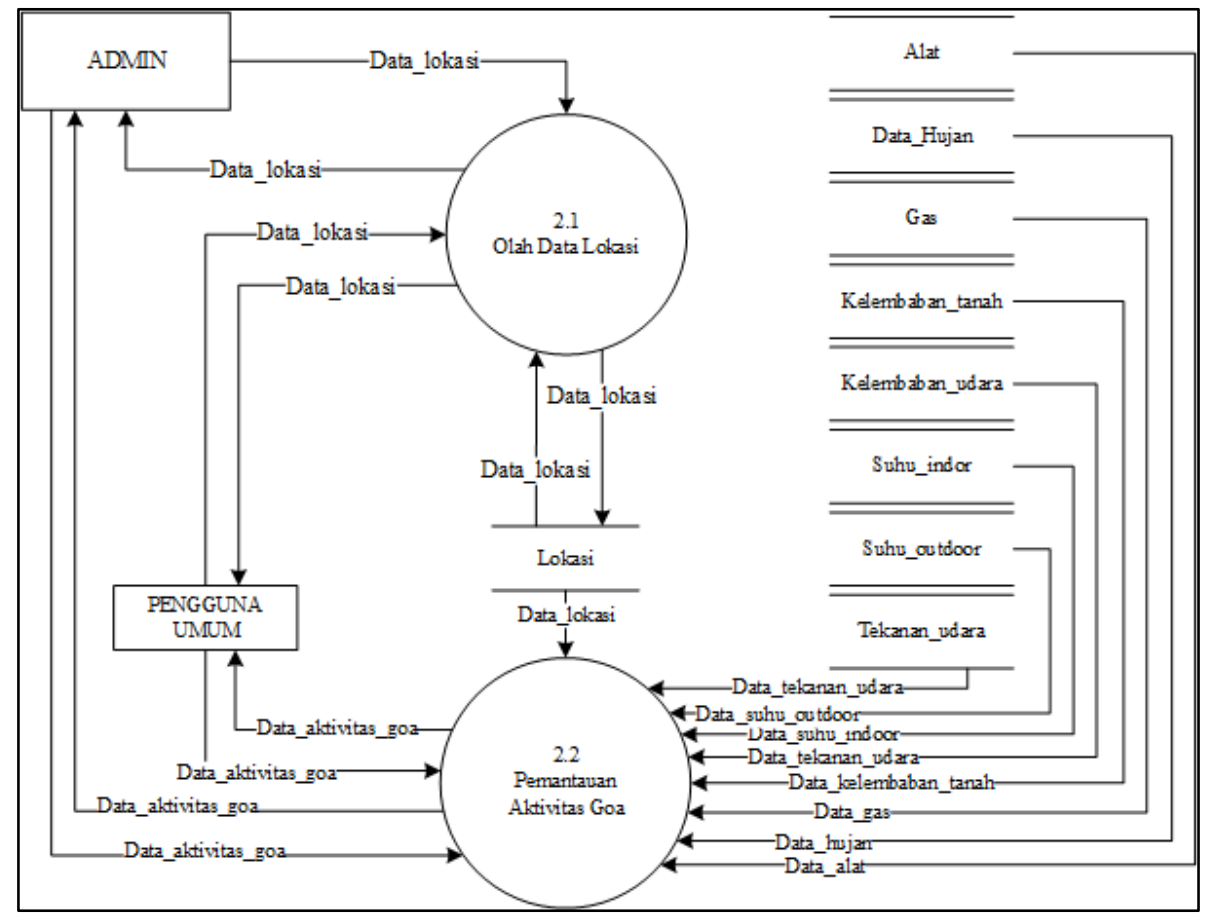

Gambar 12. DFD level 2

\subsection{Perancangan Basisdata}

Basis data merupakan salah satu komponen yang penting dalam membangun sistem. Basis data berfungsi sebagai media penyimpanan dan pengolahan data sebagai arsitektur dasar sebuah sistem.

\section{Entity Relationship Diagram (ERD)}

Entity Relationship Diagram (ERD) merupakan suatu model untuk menjelaskan hubungan antara data dalam basis data berdasarkan objek-objek dasar data yang mempunyai hubungan antar relasi. ERD digunakan untuk memodelkan struktur dan hubungan antar data untuk menggambarkannya digunakan beberapa notasi dan simbol.

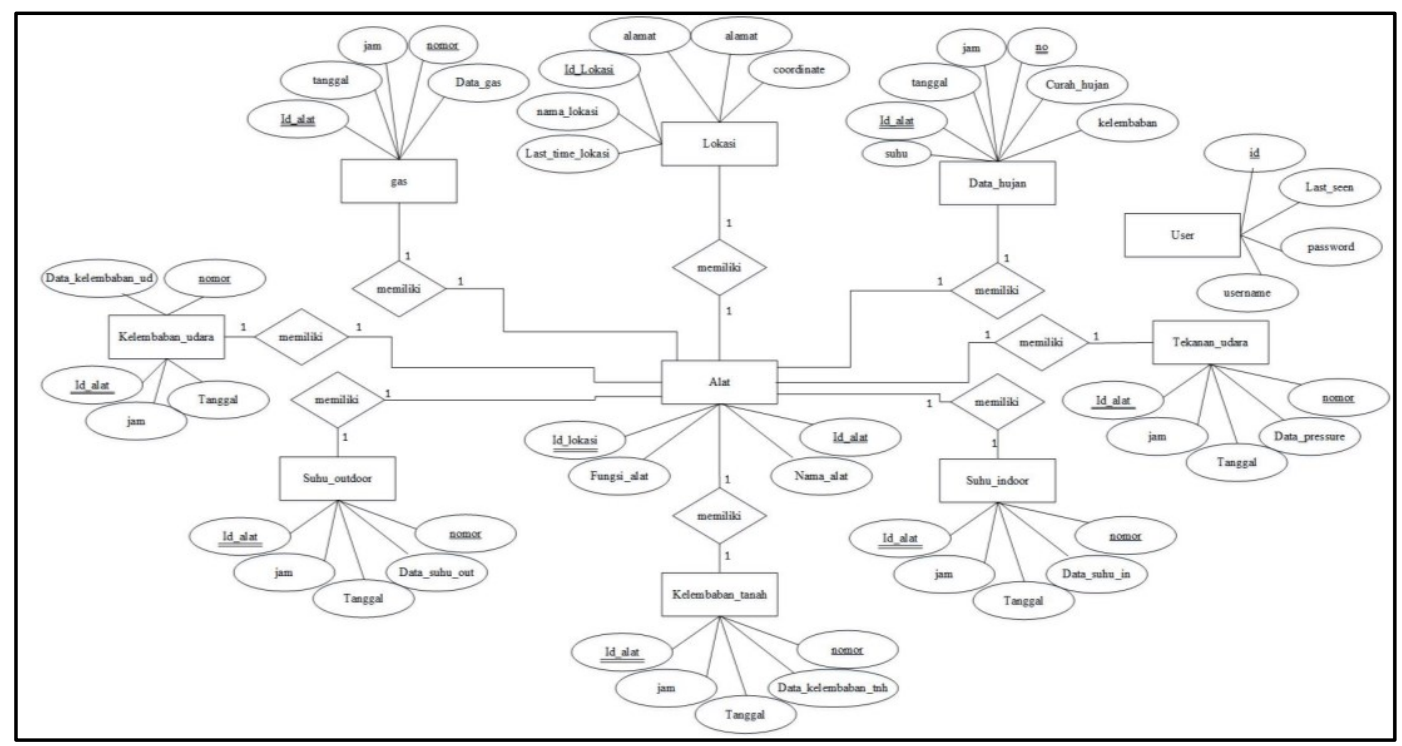

Gambar 13. ERD sistem 


\section{Relasi Antar Tabel (RAT)}

Relasi antar tabel yang terbentuk dari tabel yang telah dibuat diatas adalah seperti gambar 3.8 berikut.

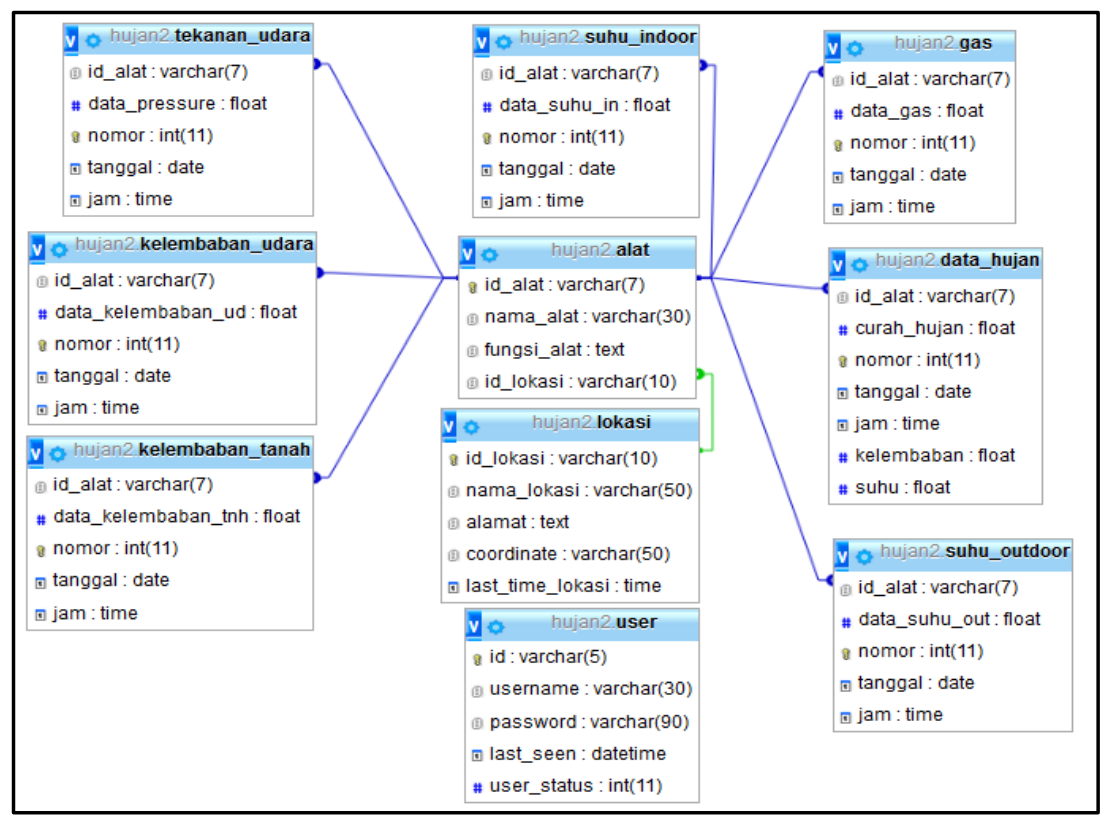

Gambar 14. RAT Sistem

\section{HASIL DAN PEMBAHASAN}

\subsection{Hasil Interface}

Setelah sistem dianalisis dan dilakukan perancangan tampilan, maka dilakukan tahap implementasi dari hasil perancangan. Hasil perancangan berupa tampilan program saat berjalan. Pada halaman user awal akan tampak seperti pada Gambar 12. dan pada halaman hasil map yang dapat diakses pengguna akan tampak seperti Gambar 13.

\begin{tabular}{|c|c|c|}
\hline \multirow[t]{2}{*}{$\leftrightarrow \rightarrow C$ 囟 } & \multirow{2}{*}{ 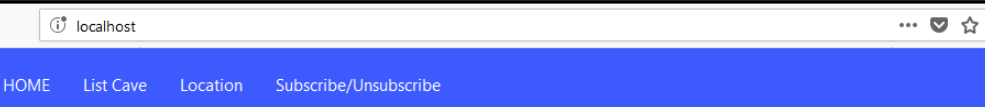 } & III $⿴ 囗 \equiv$ \\
\hline & & \\
\hline & $\begin{array}{l}\text { Gua rencang Kencono } \\
\text { Situasi Saat ini Adalah Normal yang memiliki curah hujan } 20 \mathrm{~mm} \text {. Memiliki kadar kelembaban tanah sebesar } 60 \% \text {. Memiliki kadar } \\
\text { kelembaban udara sebesar } 30 \% \text {. Suhu dalam pada Gua rencang Kencono adalah } 30^{\circ} \mathrm{C} \text {. Subu luar pada Gua rencang Kencono adalah } \\
33^{\circ} \mathrm{C}\end{array}$ & \\
\hline & 20180604/RGKC155 & \\
\hline & Q Cari Nama Goa [ex Rencang Kencono], Tanggal [ex: HARI || TANGGAL || TAHUN \| N NAMA_BULAN], Level.. & \\
\hline & $\begin{array}{l}\text { Gua rencang Kencono } \\
\text { (Wassada) } \\
2018-06-04 \\
\text { Dusun Menggoran, Dess Bleberan, } \\
\text { Kecanatan Playen, Kabupaten } \\
\text { Gunungkidul, Deerah Istimewa } \\
\text { Vogyakarta }\end{array}$ & \\
\hline & & \\
\hline
\end{tabular}

Gambar 12. Tampilan user awal 


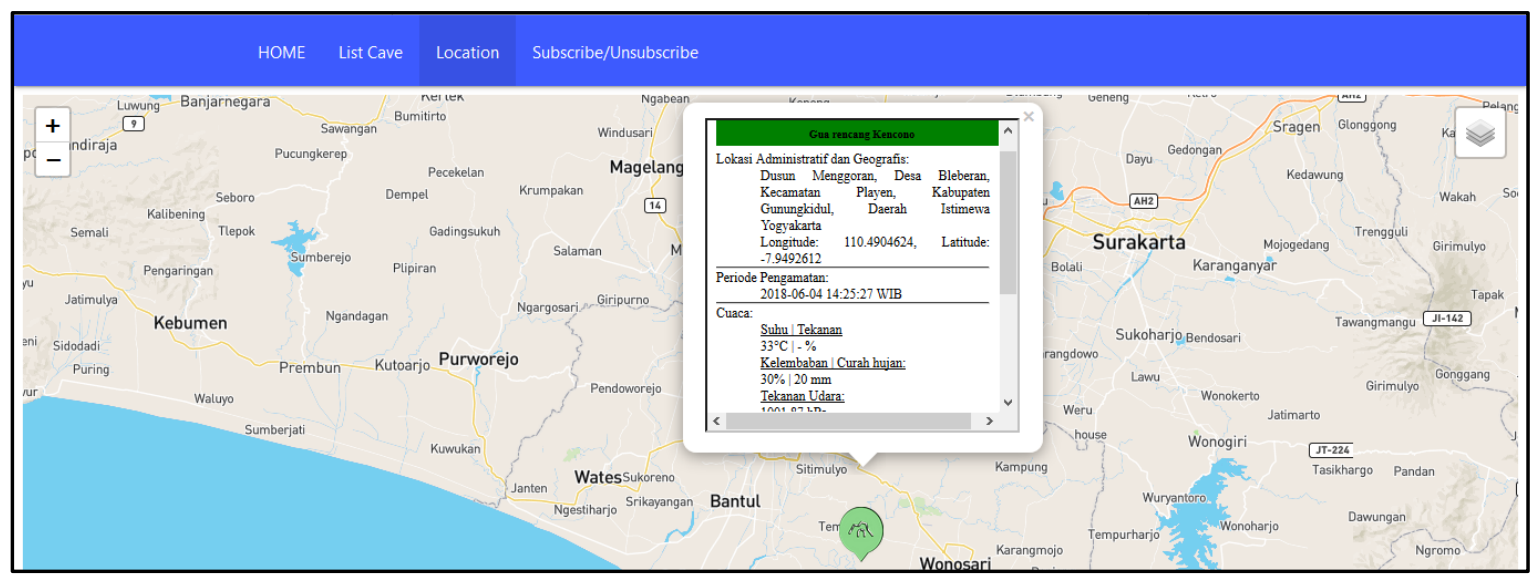

Gambar 13. Tampilan hasil peta untuk user.

\subsection{Hasil Pengujian}

Pengujian yang dilakukan berupa pengujian pada sensor dan manajemen data. Pada pengujian sensor suhu dan kelembaban, pengujian akan dilakukan pada beberapa waktu dan dengan perubahan ukuran air yang berbeda-beda dari waktu ke waktu untuk dapat mengetahui juga persentase error dari data yang dihasilkan agar mengetahui akurasi data dari alat dengan apa yang sebenarnya ada dengan perhitungan sebagai berikut:

$$
\text { persentase error }=\frac{\mid \text { hasil alat }- \text { hasil perkiraan } \mid}{\text { hasil alat }} \times 100
$$

Serta perhitungan rata-rata untuk mendapatkan akurasi dari data alat dengan jumlah pengukuran yang diambil menggunakan perhitungan sebagai berikut:

$$
\text { rata }- \text { rata }=\frac{\text { total }}{\text { jumlah pengukuran yang diambil }}
$$

Hasil pengujian pertama yang dilakukkan tampak pada tabel berikut:

Tabel 2. Tabel pengujian pertama sensor kelembaban tanah dengan air 10cc

\begin{tabular}{|c|c|c|c|c|c|}
\hline Nomor & Tanggal & Jam & Kelembaban Tanah & Suhu & Ukuran Air \\
\hline 1 & $2018-07-19$ & $10: 40: 29$ & $13 \%$ & $26{ }^{\circ} \mathrm{C}$ & $10 \mathrm{CC}$ \\
\hline 2 & $2018-07-19$ & $10: 45: 47$ & $13 \%$ & $26{ }^{\circ} \mathrm{C}$ & $10 \mathrm{CC}$ \\
\hline 3 & $2018-07-19$ & $10: 51: 04$ & $13 \%$ & $26{ }^{\circ} \mathrm{C}$ & $10 \mathrm{CC}$ \\
\hline 4 & $2018-07-19$ & $10: 56: 21$ & $13 \%$ & $26{ }^{\circ} \mathrm{C}$ & $10 \mathrm{CC}$ \\
\hline 5 & $2018-07-19$ & $11: 01: 38$ & $13 \%$ & $26{ }^{\circ} \mathrm{C}$ & $10 \mathrm{CC}$ \\
\hline 6 & $2018-07-19$ & $11: 06: 56$ & $13 \%$ & $26{ }^{\circ} \mathrm{C}$ & $10 \mathrm{CC}$ \\
\hline 7 & $2018-07-19$ & $11: 12: 14$ & $14 \%$ & $26{ }^{\circ} \mathrm{C}$ & $10 \mathrm{CC}$ \\
\hline 8 & $2018-07-19$ & $11: 17: 30$ & $14 \%$ & $26^{\circ} \mathrm{C}$ & $10 \mathrm{CC}$ \\
\hline 9 & $2018-07-19$ & $11: 22: 49$ & $14 \%$ & $26{ }^{\circ} \mathrm{C}$ & $10 \mathrm{CC}$ \\
\hline 10 & $2018-07-19$ & $11: 28: 05$ & $14 \%$ & $26{ }^{\circ} \mathrm{C}$ & $10 \mathrm{CC}$ \\
\hline 11 & $2018-07-19$ & $11: 33: 24$ & $14 \%$ & $20^{\circ} \mathrm{C}$ & $10 \mathrm{CC}$ \\
\hline 12 & $2018-07-19$ & $11: 38: 41$ & $14 \%$ & $26{ }^{\circ} \mathrm{C}$ & $10 \mathrm{CC}$ \\
\hline 13 & $2018-07-19$ & $11: 43: 58$ & $14 \%$ & $26{ }^{\circ} \mathrm{C}$ & $10 \mathrm{CC}$ \\
\hline Total & & 176 & 338 & \\
\hline Rata-rata & & 14 & 26 & \\
\hline
\end{tabular}

Dari pengumpulan data selama satu jam untuk sensor kelembaban tanah pada tanah yang diberi air sebanyak 10cc dan pada suhu 26 derajat menghasilkan 13 data, yang setidaknya ada 2 variasi hasil data yaitu $13 \%$ dan $14 \%$ yang mana total data hasil $13 \%$ kelembaban tanah tersebut adalah 
6 data dan 14\% terdapat 7 data, maka dari data diatas memiliki persentase error dengan perhitungan sebagai berikut:

$$
\begin{aligned}
& =\frac{|13-12|}{13} \times 100 \\
& =0.077 \%
\end{aligned}
$$

dan seterusnya.

Menghitung rata-rata,

$$
\text { rata }- \text { rata }=\frac{176 \%}{13}=14 \%
$$

Dari hasil perhitungan, diketahui nilai akurasi pengukuran menggunakan alat sebesar $\pm 14 \%$ untuk pengukuran kelembaban tanah dengan tegangan. Hal tersebut dikarenakan beberapa factor, diantaranya kualitas dari tiap-tiap komponen yang digunakan nilainya tidak murni. Selain itu, tegangan jala-jala listrik yang digunakan tidak stabil.

Hasil pengujian kedua yang dilakukkan tampak pada tabel berikut:

Tabel 3. Tabel pengujian kedua sensor kelembaban tanah ditambah air 10cc

\begin{tabular}{|l|l|l|l|l|l|}
\hline Nomor & Tanggal & Jam & Kelembaban Tanah & Suhu & Ukuran Air \\
\hline 1 & $19 / 07 / 2018$ & $11: 49: 19$ & $16 \%$ & $28.5{ }^{\circ} \mathrm{C}$ & $20 \mathrm{CC}$ \\
\hline 2 & $19 / 07 / 2018$ & $11: 54: 35$ & $14 \%$ & $28.82{ }^{\circ} \mathrm{C}$ & $20 \mathrm{CC}$ \\
\hline 3 & $19 / 07 / 2018$ & $11: 59: 50$ & $16 \%$ & $28.7{ }^{\circ} \mathrm{C}$ & $20 \mathrm{CC}$ \\
\hline 4 & $19 / 07 / 2018$ & $12: 05: 08$ & $21 \%$ & $28.8^{\circ} \mathrm{C}$ & $20 \mathrm{CC}$ \\
\hline 5 & $19 / 07 / 2018$ & $12: 10: 27$ & $17 \%$ & $28.7{ }^{\circ} \mathrm{C}$ & $20 \mathrm{CC}$ \\
\hline 6 & $19 / 07 / 2018$ & $12: 15: 45$ & $15 \%$ & $28.65{ }^{\circ} \mathrm{C}$ & $20 \mathrm{CC}$ \\
\hline 7 & $19 / 07 / 2018$ & $12: 21: 01$ & $14 \%$ & $28.49{ }^{\circ} \mathrm{C}$ & $20 \mathrm{CC}$ \\
\hline 8 & $19 / 07 / 2018$ & $12: 26: 18$ & $13 \%$ & $28.56{ }^{\circ} \mathrm{C}$ & $20 \mathrm{CC}$ \\
\hline 9 & $19 / 07 / 2018$ & $12: 31: 36$ & $13 \%$ & $28.48{ }^{\circ} \mathrm{C}$ & $20 \mathrm{CC}$ \\
\hline 10 & $19 / 07 / 2018$ & $12: 36: 53$ & $12 \%$ & $28.84{ }^{\circ} \mathrm{C}$ & $20 \mathrm{CC}$ \\
\hline 11 & $19 / 07 / 2018$ & $12: 42: 13$ & $12 \%$ & $28.56{ }^{\circ} \mathrm{C}$ & $20 \mathrm{CC}$ \\
\hline 12 & $19 / 07 / 2018$ & $12: 47: 28$ & $12 \%$ & $28.68{ }^{\circ} \mathrm{C}$ & $20 \mathrm{CC}$ \\
\hline 13 & $19 / 07 / 2018$ & $12: 52: 46$ & $12 \%$ & $28.6{ }^{\circ} \mathrm{C}$ & $20 \mathrm{CC}$ \\
\hline 14 & $19 / 07 / 2018$ & $12: 58: 03$ & $12 \%$ & $28.86{ }^{\circ} \mathrm{C}$ & $20 \mathrm{CC}$ \\
\hline 15 & $19 / 07 / 2018$ & $13: 03: 21$ & $12 \%$ & $29.14{ }^{\circ} \mathrm{C}$ & $20 \mathrm{CC}$ \\
\hline 16 & $19 / 07 / 2018$ & $13: 08: 41$ & $12 \%$ & $29.31{ }^{\circ} \mathrm{C}$ & $20 \mathrm{CC}$ \\
\hline 17 & $19 / 07 / 2018$ & $13: 13: 56$ & $12 \%$ & $29.02{ }^{\circ} \mathrm{C}$ & $20 \mathrm{CC}$ \\
\hline 18 & $19 / 07 / 2018$ & $13: 19: 14$ & $12 \%$ & $29.42{ }^{\circ} \mathrm{C}$ & $20 \mathrm{CC}$ \\
\hline Total & & & 247 & 518.13 & \\
\hline Rata-rata & & 13.7 & 28.78 & \\
\hline
\end{tabular}

Dari pengumpulan data selama satu jam 20 menit untuk sensor kelembaban tanah pada tanah yang diberi air tambahan sebanyak 10cc dan pada suhu yang berubah-ubah karena lingkungan menghasilkan 18 data, dengan rentan nilai $12 \%$ hingga $21 \%$, maka dari data yang didapat, terdapat persentase error dengan hitungan sebagai berikut:

$$
\begin{aligned}
& =\frac{|16-13.7|}{16} \times 100 \\
& =14.375 \%
\end{aligned}
$$


dan seterusnya.

Menghitung rata-rata,

$$
\text { Rata }- \text { rata }=\frac{247 \%}{18}=13.7 \%
$$

Dari hasil perhitungan, diketahui nilai akurasi pengukuran menggunakan alat sebesar $\pm 13.7 \%$ untuk pengukuran kelembaban tanah dengan tegangan. Hal tersebut dikarenakan beberapa faktor, diantaranya kualitas dari tiap-tiap komponen yang digunakan nilainya tidak murni. Selain itu, tegangan jala-jala listrik yang digunakan tidak stabil.

Hasil pengujian ketiga yang dilakukkan tampak pada tabel berikut:

Tabel 4. Tabel pengujian ketiga sensor kelembaban tanah ditambah air 10cc ke dua

\begin{tabular}{|l|l|l|l|l|l|}
\hline Nomor & tanggal & jam & kelembaban tanah & suhu & ukuran air \\
\hline 1 & $19 / 07 / 2018$ & $13: 24: 33$ & $40 \%$ & $27^{\circ} \mathrm{C}$ & $30 \mathrm{cc}$ \\
\hline 2 & $19 / 07 / 2018$ & $13: 29: 48$ & $25 \%$ & $27^{\circ} \mathrm{C}$ & $30 \mathrm{cc}$ \\
\hline 3 & $19 / 07 / 2018$ & $13: 35: 06$ & $20 \%$ & $27^{\circ} \mathrm{C}$ & $30 \mathrm{cc}$ \\
\hline 4 & $19 / 07 / 2018$ & $13: 40: 23$ & $17 \%$ & $27^{\circ} \mathrm{C}$ & $30 \mathrm{cc}$ \\
\hline 5 & $19 / 07 / 2018$ & $13: 45: 40$ & $15 \%$ & $27^{\circ} \mathrm{C}$ & $30 \mathrm{cc}$ \\
\hline 6 & $19 / 07 / 2018$ & $13: 53: 15$ & $13 \%$ & $27^{\circ} \mathrm{C}$ & $30 \mathrm{cc}$ \\
\hline 7 & $19 / 07 / 2018$ & $13: 58: 31$ & $13 \%$ & $27^{\circ} \mathrm{C}$ & $30 \mathrm{cc}$ \\
\hline 8 & $19 / 07 / 2018$ & $14: 03: 48$ & $13 \%$ & $27^{\circ} \mathrm{C}$ & $30 \mathrm{cc}$ \\
\hline 9 & $19 / 07 / 2018$ & $14: 09: 06$ & $13 \%$ & $26^{\circ} \mathrm{C}$ & $30 \mathrm{cc}$ \\
\hline 10 & $19 / 07 / 2018$ & $14: 14: 23$ & $13 \%$ & $26^{\circ} \mathrm{C}$ & $30 \mathrm{cc}$ \\
\hline 11 & $19 / 07 / 2018$ & $14: 19: 41$ & $13 \%$ & $26^{\circ} \mathrm{C}$ & $30 \mathrm{cc}$ \\
\hline 12 & $19 / 07 / 2018$ & $14: 24: 58$ & $13 \%$ & $26^{\circ} \mathrm{C}$ & $30 \mathrm{cc}$ \\
\hline 13 & $19 / 07 / 2018$ & $14: 30: 16$ & $14 \%$ & $26^{\circ} \mathrm{C}$ & $30 \mathrm{cc}$ \\
\hline 14 & $19 / 07 / 2018$ & $14: 35: 35$ & $14 \%$ & $26^{\circ} \mathrm{C}$ & $30 \mathrm{cc}$ \\
\hline 15 & $19 / 07 / 2018$ & $14: 40: 51$ & $14 \%$ & $26^{\circ} \mathrm{C}$ & $30 \mathrm{cc}$ \\
\hline 16 & $19 / 07 / 2018$ & $14: 46: 15$ & $15 \%$ & $26^{\circ} \mathrm{C}$ & $30 \mathrm{cc}$ \\
\hline 17 & $19 / 07 / 2018$ & $14: 51: 26$ & $15 \%$ & $26^{\circ} \mathrm{C}$ & $30 \mathrm{cc}$ \\
\hline 18 & $19 / 07 / 2018$ & $14: 56: 44$ & $15 \%$ & $26^{\circ} \mathrm{C}$ & $30 \mathrm{cc}$ \\
\hline Total & & & 295 & 476 & \\
\hline Rata-rata & & 16.38888889 & 26.44444444 & \\
\hline
\end{tabular}

Dari pengumpulan data selama satu jam 20 menit untuk sensor kelembaban tanah pada tanah yang diberi air tambahan sebanyak 10cc kedua dan pada suhu antara 26 dan 27 derajat dengan total data 18 data, dengan rentan nilai $13 \%$ hingga $40 \%$, maka dari data yang didapat, terdapat persentase error dengan hitungan sebagai berikut.

$$
\% \text { error }=\frac{|40-20|}{40} \times 100=50 \%
$$

dan seterusnya. Menghitung rata-rata,

$$
\text { Rata }- \text { rata }=\frac{295 \%}{18}=16.38889 \%
$$

Dari hasil perhitungan, diketahui nilai akurasi pengukuran menggunakan alat sebesar \pm 16.38889 $\%$ untuk pengukuran kelembaban tanah dengan tegangan. Hal tersebut dikarenakan beberapa 
faktor, diantaranya kualitas dari tiap-tiap komponen yang digunakan nilainya tidak murni. Selain itu, tegangan jala-jala listrik yang digunakan tidak stabil.

Hasil pengujian keempat yang dilakukkan tampak pada tabel berikut:

Tabel 5. Tabel pengujian keempat sensor kelembaban tanah ditambah air 20cc

\begin{tabular}{|c|c|c|c|c|c|}
\hline Nomor & Tanggal & Jam & Kelembaban Tanah & Suhu & Ukuran Air \\
\hline 1 & $19 / 07 / 2018$ & $22: 19: 56$ & $26 \%$ & $26^{\circ} \mathrm{C}$ & $50 \mathrm{cc}$ \\
\hline 2 & $19 / 07 / 2018$ & $22: 25: 14$ & $26 \%$ & $26^{\circ} \mathrm{C}$ & $50 \mathrm{cc}$ \\
\hline 3 & $19 / 07 / 2018$ & $22: 30: 31$ & $23 \%$ & $26^{\circ} \mathrm{C}$ & $50 \mathrm{cc}$ \\
\hline 4 & $19 / 07 / 2018$ & $22: 35: 49$ & $23 \%$ & $25^{\circ} \mathrm{C}$ & $50 \mathrm{cc}$ \\
\hline 5 & $19 / 07 / 2018$ & 22:41:06 & $22 \%$ & $25^{\circ} \mathrm{C}$ & $50 \mathrm{cc}$ \\
\hline 6 & $19 / 07 / 2018$ & $22: 46: 23$ & $23 \%$ & $25^{\circ} \mathrm{C}$ & $50 \mathrm{cc}$ \\
\hline 7 & $19 / 07 / 2018$ & $22: 51: 41$ & $25 \%$ & $25^{\circ} \mathrm{C}$ & $50 \mathrm{cc}$ \\
\hline 8 & $19 / 07 / 2018$ & $22: 56: 58$ & $24 \%$ & $25^{\circ} \mathrm{C}$ & $50 \mathrm{cc}$ \\
\hline 9 & $19 / 07 / 2018$ & $23: 02: 16$ & $23 \%$ & $25^{\circ} \mathrm{C}$ & $50 \mathrm{cc}$ \\
\hline 10 & $19 / 07 / 2018$ & 23:07:34 & $23 \%$ & $25^{\circ} \mathrm{C}$ & $50 \mathrm{cc}$ \\
\hline 11 & $19 / 07 / 2018$ & $23: 12: 51$ & $23 \%$ & $25^{\circ} \mathrm{C}$ & $50 \mathrm{cc}$ \\
\hline 12 & $19 / 07 / 2018$ & $23: 18: 08$ & $23 \%$ & $25^{\circ} \mathrm{C}$ & $50 \mathrm{cc}$ \\
\hline 13 & $19 / 07 / 2018$ & 23:23:26 & $22 \%$ & $25^{\circ} \mathrm{C}$ & $50 \mathrm{cc}$ \\
\hline 14 & $19 / 07 / 2018$ & 23:28:43 & $21 \%$ & $25^{\circ} \mathrm{C}$ & $50 \mathrm{cc}$ \\
\hline 15 & $19 / 07 / 2018$ & 23:34:01 & $20 \%$ & $25^{\circ} \mathrm{C}$ & $50 \mathrm{cc}$ \\
\hline 16 & $19 / 07 / 2018$ & $23: 39: 18$ & $19 \%$ & $25^{\circ} \mathrm{C}$ & $50 \mathrm{cc}$ \\
\hline 17 & $19 / 07 / 2018$ & $23: 44: 36$ & $18 \%$ & $25^{\circ} \mathrm{C}$ & $50 \mathrm{cc}$ \\
\hline 18 & $19 / 07 / 2018$ & $23: 49: 53$ & $18 \%$ & $25^{\circ} \mathrm{C}$ & $50 \mathrm{cc}$ \\
\hline 19 & $19 / 07 / 2018$ & 23:55:11 & $19 \%$ & $25^{\circ} \mathrm{C}$ & $50 \mathrm{cc}$ \\
\hline 20 & $20 / 07 / 2018$ & $00: 00: 28$ & $19 \%$ & $25^{\circ} \mathrm{C}$ & $50 \mathrm{cc}$ \\
\hline 21 & $20 / 07 / 2018$ & 00:05:51 & $19 \%$ & $25^{\circ} \mathrm{C}$ & $50 \mathrm{cc}$ \\
\hline 22 & $20 / 07 / 2018$ & $00: 11: 03$ & $19 \%$ & $25^{\circ} \mathrm{C}$ & $50 \mathrm{cc}$ \\
\hline 23 & $20 / 07 / 2018$ & $00: 16: 21$ & $18 \%$ & $25^{\circ} \mathrm{C}$ & $50 \mathrm{cc}$ \\
\hline 24 & $20 / 07 / 2018$ & $00: 21: 39$ & $17 \%$ & $25^{\circ} \mathrm{C}$ & $50 \mathrm{cc}$ \\
\hline 25 & $20 / 07 / 2018$ & $00: 26: 55$ & $16 \%$ & $25^{\circ} \mathrm{C}$ & $50 \mathrm{cc}$ \\
\hline 26 & $20 / 07 / 2018$ & $00: 32: 13$ & $17 \%$ & $25^{\circ} \mathrm{C}$ & $50 \mathrm{cc}$ \\
\hline 27 & $20 / 07 / 2018$ & $00: 37: 30$ & $16 \%$ & $25^{\circ} \mathrm{C}$ & $50 \mathrm{cc}$ \\
\hline 28 & $20 / 07 / 2018$ & $00: 42: 48$ & $15 \%$ & $25^{\circ} \mathrm{C}$ & $50 \mathrm{cc}$ \\
\hline 29 & $20 / 07 / 2018$ & 00:48:05 & $13 \%$ & $25^{\circ} \mathrm{C}$ & $50 \mathrm{cc}$ \\
\hline 30 & $20 / 07 / 2018$ & $00: 53: 23$ & $12 \%$ & $25^{\circ} \mathrm{C}$ & $50 \mathrm{cc}$ \\
\hline 31 & $20 / 07 / 2018$ & 00:58:40 & $12 \%$ & $25^{\circ} \mathrm{C}$ & $50 \mathrm{cc}$ \\
\hline 32 & $20 / 07 / 2018$ & 01:03:58 & $12 \%$ & $25^{\circ} \mathrm{C}$ & $50 \mathrm{cc}$ \\
\hline 33 & $20 / 07 / 2018$ & 01:09:15 & $12 \%$ & $25^{\circ} \mathrm{C}$ & $50 \mathrm{cc}$ \\
\hline 34 & $20 / 07 / 2018$ & 01:14:33 & $13 \%$ & $25^{\circ} \mathrm{C}$ & $50 \mathrm{cc}$ \\
\hline 35 & $20 / 07 / 2018$ & 01:19:50 & $14 \%$ & $25^{\circ} \mathrm{C}$ & $50 \mathrm{cc}$ \\
\hline 36 & $20 / 07 / 2018$ & $01: 25: 07$ & $15 \%$ & $25^{\circ} \mathrm{C}$ & $50 \mathrm{cc}$ \\
\hline 37 & $20 / 07 / 2018$ & 01:30:25 & $16 \%$ & $25^{\circ} \mathrm{C}$ & $50 \mathrm{cc}$ \\
\hline 38 & $20 / 07 / 2018$ & $01: 35: 42$ & $14 \%$ & $25^{\circ} \mathrm{C}$ & $50 \mathrm{cc}$ \\
\hline
\end{tabular}




\begin{tabular}{|l|l|l|l|}
\hline Total & $710 \%$ & 953 & \\
\hline Rata-rata & 18.68321053 & 25.07894737 & \\
\hline
\end{tabular}

Dari pengumpulan data selama satu jam 35 menit untuk sensor kelembaban tanah pada tanah yang diberi air tambahan sebanyak 10cc kedua dan pada suhu 25 derajat dengan total data 38 data, dengan rentan nilai $12 \%$ hingga $26 \%$, maka dari data yang didapat, terdapat persentase error dengan hitungan sebagai berikut.

$$
\% \text { error }=\frac{|19-25|}{19} \times 100=31.57 \%
$$

dan seterusnya. Menghitung rata-rata,

$$
\text { Rata }- \text { rata }=\frac{710 \%}{38}=18.6821053 \%
$$

Dari hasil perhitungan, diketahui nilai akurasi pengukuran menggunakan alat sebesar \pm $18.68421053 \%$ untuk pengukuran kelembaban tanah dengan tegangan. Hal tersebut dikarenakan beberapa faktor, diantaranya kualitas dari tiap-tiap komponen yang digunakan nilainya tidak murni. Selain itu, tegangan jala-jala listrik yang digunakan tidak stabil.

Dari data-data hasil pengujian alat diatas, dapat disimpulkan bahwa tegangan akurasi alat bisa berbeda-beda pada setiap waktu dikarenakan beberapa factor seperti kualitas komponen yang digunakan, tegangan yang digunakan serta tegangan yang dihasilkan yang mungkin bisa jadi tidak stabil.

\subsection{Pembahasan}

Hasil pengujian menajemen data dapat diperoleh bahwa sistem sudah sesuai dengan perancangan dan beberapa navigasi serta link untuk perubahan dan penambahan data juga berjalan baik. Kelebihan sistem ini adalah sistem mampu memberikan informasi peringatan dan level status aktivitas gua. Data aktivitas ini akan ditampilkan pada hampir seluruh halaman yang nantinya data tersebut akan update setiap detik atau setiap ada perubahan level status aktivitasi gua. Dari pengujian sensor, ketika daya tegangan yang diberikan lebih tinggi, perbedaan suhu semakin sedikit, mendekati atau sama dengan suhu yang diukur dengan bantuan alat lain seperti termometer. Hasil dari pengujian alat juga menandakan ke akuratan alat dari tabel 2 hingga tabel 5 yang memberikan perbedaan error pada tiap percobaan yang dibedakan takaran-takaran nya agar mengetahui resistensi sensor terhadap perubahan takaran.

\section{KESIMPULAN}

Berdasarkan hasil dari analisis, perancangan, dan pembahasan yang telah dilakukan, maka dihasilkan sebuah sistem yang memberikan pengawasan dan peringatan dini pada gua. Kesimpulan yang dapat diambil pada penelitian ini antara lain:

1. Sistem pengawasan dan peringatan dini ini mampu memberikan pengamatan yang dilakukan dengan cepat dengan data yang diperbaharui secara realtime secara terus menerus oleh sensor-sensor yang di unggah pada database cloud yang mana setelah data-data tersebut terbaca dan masuk pada salah satu kategori level seperti waspada, awas dan siaga, maka mampu menghasilkan peringatan oleh sistem.

2. Peringatan yang diberikan sistem berupa suara sirine yang memiliki perbedaan suara dari beberapa level untuk waspada, awas dan siaga.

3. Pengawasan dengan sistem yang mengambil dari data sensor pembaca seperti pembaca curah hujan, suhu ruang dalam, suhu ruang luar, kelembaban udara, kelembaban tanah, tekanan udara, dan gas karbon kemudian di simpulkan sebagai level aktivitasi gua.

4. Pada penelitian ini, cloud digunakan sebagai media untuk menanamkan server, dimana sistem yang berada dalam server dapat digunakan sebagai media penyimpanan data record sensor, sehingga lebih mudah di akses dan data lebih aman. 


\section{DAFTAR PUSTAKA}

Alphonsa A, \& Ravi G. (016). Earthquake Early Warning System by IOT using Wireless Sensor Networks, 1201-1205.

Ambarwati, N. D. (2008). Potensi dan pengembangan Obyek wisata alam gua tembus di kabupaten wonogiri (PhD Thesis). Universitas Sebelas Maret.

Beimborn, D., Miletzki, T., \& Wenzel, S. (2011). Platform As A Service (Paas) Sebagai Layanan Sistem Operasi Cloud Computing. Business and Information Systems Engineering, 3(6), 381-384. https://doi.org/10.1007/s12599-011-0183-3

BMKG. n.d. "Prakiraan Hujan Bulanan | BMKG." BMKG | Badan Meteorologi, Klimatologi, dan Geofisika. Accessed August 2, 2018. http://www.bmkg.go.id/iklim/prakiraan-hujanbulanan.bmkg.

Chang, N., \& Guo, D.-H. (2006). Urban flash flood monitoring, mapping and forecasting via a tailored sensor network system. 2006 IEEE International Conference on Networking, Sensing and Control, 757-761. https://doi.org/10.1109/ICNSC.2006.1673241

Das, R. K., \& Misra, H. (2017). Smart city and E-Governance: Exploring the connect in the context of local development in India. 2017 4th International Conference on eDemocracy and eGovernment, ICEDEG 2017, 232-233.

ttps://doi.org/10.1109//CEDEG.2017.7962540

Endroyono, E., Affandi, A., Setijadi, E., Kusrahardjo, G., \& Suprajitno, D. (2017). Inovasi SIECITS dalam Implementasi Teknologi Informasi dan [Tele] Komunikasi Mendukung Framework Smart-city yang Berkelanjutan. IPTEK Proceedings Series.

Faisela, R. Y. (2018). Pengembangan Layanan Infrastructure As A Service (laas) Untuk Laboratorium Virtual Menggunakan Platform Orchestration Pada Openstack.

Fujiwara, Y., Yamada, K., Tabata, K., Oda, M., Hashimoto, K., Suganuma, T., Georgakopoulos, A. (2015). Context aware services: A novel trend in iot based research in smart city project. Proceedings - International Computer Software and Applications Conference, 3, 479-480. https://doi.org/10.1109/COMPSAC.2015.319

Gold, R., Brown, J. S., Sprague, B., \& Bruce, R. (1999). The origins of research at PARC, 38(4), 693-696.

Hamalainen, M., \& Tyrvainen, P. (2016). A Framework for loT Service Experiment Platforms in Smart-City Environments.

Harmony, G., \& Agus Joko Pitoyo. (2012). Kajian Potensi Gua Sebagai Arahan Wisata Minat Khusus Penelusuran Gua Di Pulau Nusakambangan, 1(3), 20-28.

Hayati, Jamilah, Santun R P Sitorus, and Siti Nurisjah. 2013. "Pengembangan Ruang Terbuka Hijau Dengan Pendekatan Kota Hijau Di Kota Kandangan.” Jurnal Tataloka 15 (4): 306. https://doi.org/10.14710/tataloka.15.4.306-316.

sKussul, N., Skakun, S., Shelestov, A. Y., Kussul, O., \& Yailymov, B. (2014). Resilience aspects in the sensor web infrastructure for natural disaster monitoring and risk assessment based on earth observation data. IEEE Journal of Selected Topics in Applied Earth Observations and Remote Sensing, 7(9), 3826-3832. https://doi.org/10.1109/JSTARS.2014.2313573

Liu, Q., Wang, G., Liu, X., Peng, T., \& Wu, J. (2017). Achieving reliable and secure services in cloud computing environments. Computers and Electrical Engineering, 59, 153-164. https://doi.org/10.1016/j.compeleceng.2016.10.005 
Lopez Research. (2013). An Introduction to the Internet of Things (IoT). Lopez Research Llc, Part 1. of(November), 1-6.

Management, B. (2015). Environmental Guideline For Environmental Guideline for Smart Cities. Ministry of Environment, Sustanable Development, and Disaster and Beach Management, (July), 1-18.

Monzon, A. (2015). Smart Cities and Green ICT Systems (SMARTGREENS), 2015 International Conference on. Smart Cities and Green ICT Systems (SMARTGREENS), 2015 International Conference on, 1-11.

Morreale, P., Qi, F., Croft, P., Suleski, R., Sinnicke, B., \& Ken3dall, F. (2010). Real-time environmental monitoring and notification for public safety. IEEE Multimedia, 17(2), 4-11. https://doi.org/10.1109/MMUL.2010.37

Na, A., \& Isaac, W. (2016). Developing a Human-Centric Agricultural Model in the loT Environment, 1-6. https://doi.org/10.1109/IOTA.2016.7562740

Nam, T., \& Pardo, T. A. (2011). Conceptualizing Smart City with Dimensions of Technology, People, and Institutions, 282-291.

Patk-cornell, M. E. (1986). Warning Systems in Risk Management, 6(2).

Poslad, S., Middleton, S. E., Member, S., Chaves, F., Tao, R. A. N., Necmioglu, O., \& Bügel, U. (2015). A Semantic loT Early Warning System for Natural Environment Crisis Management, 3(2).

Singh, D. (2016). mKRISHI ® Fisheries: A case study on Early Warning System ( EWS ) for Disaster Communication and Management, (October), 106-111.

Suhartono, Y., Atmaja, Y., \& Lambang, R. P. (2008). Studi Konservasi Lukisan Gua Prasejarah di Maros dan Pangkep. Balai Konservasi Peninggalan Borobudur.

Wladdimiro, D., Gonzalez-cantergiani, P., Hidalgo, N., \& Rosas, E. (n.d.). Disaster Management Platform to Support Real-time Analytics.

Yuwono, B., Nugroho, S. P., Studi, P., \& Informatika, T. (2015). Pengembangan Model Public Monitoring System, 12(2), 123-133. 